Article

\title{
Feasibility of Utilizing Biodegradable Plastic Film to Cover Corn Silage under Farm Conditions
}

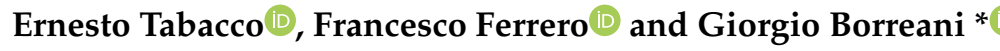 \\ Department of Agricultural, Forest and Food Sciences (DISAFA), University of Turin, Largo Braccini 2, \\ 10095 Grugliasco (TO), Italy; ernesto.tabacco@unito.it (E.T.); francesco.ferrero@unito.it (F.F.) \\ * Correspondence: giorgio.borreani@unito.it; Tel.: +39-0116-708-783
}

Received: 7 April 2020; Accepted: 15 April 2020; Published: 17 April 2020

\begin{abstract}
The degree of anaerobiosis and its maintenance over the conservation period are key factors in obtaining high quality silage. There is currently a demand to replace petroleum-based plastic films with biodegradable materials with suitable mechanical properties. This work has evaluated, under outdoor conditions, the shelf life of a Mater-Bi ${ }^{\circledR}$ biodegradable plastic (MB) film and its effects on the fermentative characteristics, microbial counts and aerobic stability of corn silage, and compared it with commercially available polyethylene (PE) and high oxygen barrier (OB) films. Corn ( $409 \mathrm{~g} \mathrm{DM} / \mathrm{kg}$ ) was ensiled in 30 drive-over piles covered with MB, PE or OB films. The piles were opened after 21, 85, 133, 195 and $230 \mathrm{~d}$ of conservation. The effect of the film was assessed in silage sample close to (CF) and far (FF) from the film. The OB film allowed high quality corn silages to be obtained with similar $\mathrm{pH}$, lactic acid, yeast and mold counts for $\mathrm{CF}$ and $\mathrm{FF}$ during the entire $230 \mathrm{~d}$ of conservation. The PE film showed similar values for the FF and CF areas for the first conservation period (until $133 \mathrm{~d}$ ). The MB film showed a similar silage quality to $\mathrm{OB}$ until day 85 , after which it underwent biodegradation and lost its ability to preserve silage in a good state.
\end{abstract}

Keywords: biodegradable film; farm conditions; Mater-Bi ${ }^{\circledR}$; oxygen barrier film; polyethylene film; silage quality

\section{Introduction}

Whole-plant corn silage has become the predominant forage to provide fibre and energy in dairy cattle diets, and it is generally conserved worldwide through ensiling [1]. The success and efficiency of silage depend on the acidification that occurs when, in an anaerobic environment, a sufficient amount of lactic acid is produced by the population of lactic acid bacteria present in the forage at harvesting [2]. The degree of anaerobiosis reached in the filled silo and its maintenance over the entire conservation period are key factors in obtaining a high quality silage [3,4]. If the air-tight sealing of the silo is not ensured, air penetrates the silage, and aerobic microorganisms multiply, thereby triggering aerobic deterioration and causing dry matter (DM) losses which, in the peripheral area of the silo, can exceed $35 \%$ [5]. Therefore, the ensiling technique requires an absolutely air-tight environment which, until the fifties, could only be attained through the use of constructions made of concrete or steel. In those structures, silages were either not covered or covered with organic material, such as manure, with high concerns about the microbial quality of the silages. The introduction, in the early 1950s, of plastic sheeting to cover silage was a milestone of great significance [6] and most silages were covered from the beginning of the 1960 's until 2000 with plastic film based on low density polyethylene (PE) $[7,8]$. The use of a polyethylene film (125-250 $\mu \mathrm{m}$ thickness, including plasticizers and ultraviolet stabilizers to prevent the material from disintegrating under sunlight) became, by the mid-1970s, the conventional method of covering horizontal silos, and this practice essentially remained unchanged for 30 years until the development of co-extruded films with reduced permeability to oxygen [4]. These new oxygen 
barrier films (OB), which are made by coextruding a layer of barrier polymer (ethylene-vinyl alcohol copolymer (EVOH) or polyamide (PA)) between two or more layers of low density PE, have shown benefits pertaining to improvements in the quality of peripheral areas in bunker silos as a result of the increased uniformity of the whole profile of the silo during the feed-out phase [5,9]. The main benefits are a better prevention of the growth of pathogenic and mycotoxigenic molds during conservation [10], a delay in their growth after the exposure of the silage to air [11], and a reduction in the DM losses of the overall ensiling system, compared to film made of PE alone [5,12].

On the other hand, the disposal of PE and OB films can represent a potential environmental concern, because they can only be used once, and they are non-biodegradable, difficult to recycle and are rarely disposed of correctly $[13,14]$. The current disposal methods include transferring silage plastics to a solid waste station or plowing them into the ground, and it often happens that silage plastic covers are burned directly in an open fire on the farms, causing the release of toxic volatile compounds, which are dangerous for human and environmental health [14-16]. Above all for these reasons, in the last two decades, much attention has been paid to replacing petroleum-based plastic films with cost-effective alternatives, such as organic covers $[17,18]$ or biodegradable materials with suitable mechanical properties [9] to protect silage. New biodegradable plastics, made of renewable resources, are becoming more and more available on the market, thanks to the efforts of chemical engineering and biotechnology companies [13,19]. Bioplastics are defined as those innovative materials that are bio-based (i.e. derived from renewable resources) and fully biodegradable (and which may be completely converted, by microorganisms, into carbon dioxide, water, minerals and microbial biomass, without leaving any potentially harmful substances in the environment). Mater- $\mathrm{Bi}^{\circledR}{ }^{\circledR}$ is the first completely biodegradable and compostable bio-based polymer ever invented [20] and it has been shown to be suitable for the production of films of different thickness that could be utilized to cover silage [21,22]. Its main drawbacks are its instability over time and its proneness to begin biodegradation during silage conservation, features which could cancel out the capacity of maintaining the anaerobic environment that is indispensable for an ensiling process. This biodegradable plastic film has been shown to be able to work well for conservation periods longer than 5 months under indoor conditions [9], but is less effective when utilized to cover silage under outdoor conditions [23].

The aim of this work has been to evaluate, under outdoor conditions at a farm level, the shelf life of a bio-based biodegradable film considering a new stabilized Mater-Bi ${ }^{\circledR}$ formulation utilized to cover silage and to compare it with commercially available $\mathrm{PE}$ and $\mathrm{OB}$ films, in particular pertaining to the fermentative characteristics, microbial counts and aerobic stability of corn silage ensiled in drive over piles.

\section{Materials and Methods}

The research was conducted at the University of Turin experimental farm in the western Po plain, northern Italy $\left(44^{\circ} 53^{\prime} \mathrm{N}, 7^{\circ} 41^{\prime} \mathrm{E}\right.$, altitude $232 \mathrm{~m}$ a.s.l.) on whole-plant corn silage (Zea mays L.).

\subsection{Crop and Ensiling Procedure}

A corn hybrid (P1547, Pioneer Hi-Bred Italia Srl, Gadesco Pieve Delmona, Cremona, Italy) was sown in April, at an intended planting density of 75,000 seeds/ha, in an experimental field of about $3 \mathrm{ha}$. The experimental field received $100 \mathrm{~kg} / \mathrm{ha} \mathrm{K}_{2} \mathrm{O}$ (as potassium chloride) before sowing, 39 and $100 \mathrm{~kg} / \mathrm{ha}$ of $\mathrm{N}$ and $\mathrm{P}_{2} \mathrm{O}_{5}$ (as diammonium phosphate) at sowing and $120 \mathrm{~kg} / \mathrm{ha} \mathrm{N}$, as urea, at the six leaf stage. The crop was irrigated twice during the growing season. Weed control was performed utilizing mesotrione ( $0.15 \mathrm{~kg} \mathrm{AI} / \mathrm{ha})$, S-metolachlor (1.25 kg AI/ha) and terbuthylazine $(0.75 \mathrm{~kg} \mathrm{AI} / \mathrm{ha})$ (Lumax ${ }^{\circledR}$, Syngenta Crop Protection S.p.A., Milan, Italy). Corn was harvested at around the $75 \%$ milk-line stage and with a DM content of $409 \mathrm{~g} \mathrm{DM} / \mathrm{kg}$ of fresh forage. The forage was chopped, using a self propelled forage harvester (Claas Jaguar 950, equipped with an 8-row Orbis head, Claas, Harsewinkel, Germany), to a theoretical 10-mm length of cut, and ensiled within 2 hours in drive-over piles. Each pile contained around $4 \mathrm{t}$ of fresh forage and was 6 meters long, 3 meters wide and 
$1 \mathrm{~m}$ high at the top of the pile. The experiment was organized in a 3 (plastic films) $\times 5$ (times of conservation) factorial treatment arrangement, with two drive-over experimental piles per treatment (for a total of 30 experimental piles). The three sealing materials were: (a) a single $200 \mu \mathrm{m}$ thick (6 m wide) black-on-white polyethylene, UV protected film (PE); (b) a single $130 \mu \mathrm{m}$ thick (6 m wide) black-on-white co-extruded polyethylene-special grade EVOH (SoarnoL TM SG611B, Nippon Gohsei, Osaka, Japan) UV protected film, with a high oxygen barrier (OB); (c) a single $120 \mu \mathrm{m}$ thick (4 m wide), transparent milky Mater-Bi ${ }^{\circledR}$ (Novamont SpA, Novara, Italy) biodegradable plastic film (MB). The oxygen permeability of the films, determined on the basis of the American Society for Testing and Materials' (ASTM) standard method D 3985-81 [24], at 1 bar, at $23^{\circ} \mathrm{C}$ and at $90 \%$ relative humidity (RH), was 1196,9 , and $483 \mathrm{~cm}^{3} / \mathrm{m}^{2}$ per $24 \mathrm{~h}$ for $\mathrm{PE}, \mathrm{OB}$ and $\mathrm{MB}$, respectively. The water vapor transmission rate (WVTR), determined on the basis of ASTM F1249-06 [25], was $1.05 \mathrm{~g} / \mathrm{m}^{2}, 1.6 \mathrm{~g} \mathrm{~m}^{-2}$, and $17.4 \mathrm{gm}^{2}$ (per $24 \mathrm{~h}$ at $38^{\circ} \mathrm{C}$ and $90 \% \mathrm{RH}$ ) for $\mathrm{PE}, \mathrm{OB}$ and $\mathrm{MB}$, respectively. Each pile was covered with a PE (10 piles), an OB (10 piles) or an MB film (10 piles). The plastic sheets were held in place by putting gravel all around the silage. Two silos were opened for each treatment after 21, 85, 133, 195 and $230 \mathrm{~d}$ of conservation. Furthermore, the effect of the distance from the plastic film was assessed in silage stored in two zones of the silo: close to the film, from 0 to $300 \mathrm{~mm}(\mathbf{C F})$, and deeper, that is, from 600 to $900 \mathrm{~mm}$ (FF). This resulted in six treatments: close to the polyethylene film (PE-CF), at a distance from the polyethylene film (PE-FF), close to the oxygen barrier film (OB-CF), at a distance from the oxygen barrier film (OB-FF), close to the biodegradable film (MB-CF) and at a distance from the biodegradable film (MB-FF). Two independent samples (of about ten kilograms of fresh weight) were sampled at each location and for each pile, for a total of four samples per treatment and per opening date. After sampling, the silages were subjected to an aerobic stability test by monitoring the temperature increases due to the microbial activity of the samples exposed to air. About three kilograms of each sample was allowed to aerobically deteriorate at room temperature $\left(20 \pm 1.0^{\circ} \mathrm{C}\right)$ in $17 \mathrm{~L}$ polystyrene boxes $(290 \mathrm{~mm}$ diameter and $260 \mathrm{~mm}$ height). A single layer of aluminum foil was placed over each box to prevent drying and dust contamination, but also to allow the air to penetrate. The temperatures of the room and of the silage were measured hourly by a data logger. Aerobic stability was defined as the number of hours the silage remained stable before its temperature increased $2{ }^{\circ} \mathrm{C}$ above room temperature.

\subsection{Sample Preparation and Analyses}

The pre-ensiled material and the silages were split into five subsamples. One sub-sample was analyzed immediately for the DM content by oven drying at $80^{\circ} \mathrm{C}$ for $24 \mathrm{~h}$. Dry matter was corrected according to [26] in order to consider the volatile compound losses that can take place at $80^{\circ} \mathrm{C}$.

The second subsample was oven-dried at $65^{\circ} \mathrm{C}$ to constant weight and was air equilibrated, weighed and ground in a Cyclotec mill (Tecator, Herndon, VA, USA) to pass a $1 \mathrm{~mm}$ screen. The dried samples were analyzed for total nitrogen (TN), according to the Dumas method (method number 992.23, [27]), using a Nitrogen Primacs SN (Skalar, Breda, The Netherlands), for crude protein (CP) (total N x 6.25) and for ash by ignition (method number 942.05, [28]). Neutral detergent fiber (aNDF) was analyzed, using a Raw Fiber Extractor (FIWE, VELP Scientifica, Usmate Velate, IT), with the addition of heat-stable amylase (A3306, Sigma Chemical Co., St. Louis, MO, USA) and expressed on a DM basis, including residual ash, as described by Van Soest et al. [29]. Acid detergent fiber (ADF) was analyzed and expressed on a DM basis, including residual ash [30].

A third fresh sub-sample was used to determine the water activity $\left(\mathrm{a}_{\mathrm{w}}\right), \mathrm{pH}$, nitrate $\left(\mathrm{NO}_{3}\right)$ and ammonia nitrogen $\left(\mathrm{NH}_{3}-\mathrm{N}\right)$ contents and the buffering capacity $(\mathrm{BC})$. The fresh forage was extracted for $\mathrm{pH}, \mathrm{NO}_{3}$ and $\mathrm{NH}_{3}-\mathrm{N}$ determination, using a Stomacher blender (Seward Ltd, Worthing, UK), for 4 min in distilled water at a 9:1 water-to-sample material (fresh weight) ratio. The total nitrate concentration was determined in the water extract, through semi-quantitative analysis, using Merckoquant test strips (Merck, Darmstadt, Germany; detection limit $100 \mathrm{mg} \mathrm{NO}_{3} / \mathrm{kg}$ ). The ammonia nitrogen content and $\mathrm{pH}$ were determined using specific electrodes. The buffering capacity was determined in the water extract, as described by Playne and McDonald [31]. 
A fourth sub-sample was extracted, using a Stomacher blender, for 4 min in $\mathrm{H}_{2} \mathrm{SO}_{4} 0.05 \mathrm{~mol} / \mathrm{L}$ at a 4:1 acid-to-sample material (fresh weight) ratio. An aliquot of $40 \mathrm{~mL}$ of silage acid extract was filtered with a $0.20-\mu \mathrm{m}$ syringe filter and used for quantification of the fermentation products. The lactic and monocarboxylic acids (acetic, propionic and butyric acids) were determined, by means of high performance liquid chromatography (HPLC), in the acid extract [32]. Ethanol, 1-propanol and 1,2-propanediol were determined by means of HPLC, coupled to a refractive index detector, on an Aminex HPX-87H column (Bio-Rad Laboratories, Richmond, CA, USA).

The fifth subsample was used for microbial counts. Thirty grams of sample was transferred to a sterile homogenization bag, suspended 1:10 w/v in a peptone salt solution $(1 \mathrm{~g}$ of bacteriological peptone and $9 \mathrm{~g}$ of sodium chloride per litre) and homogenized for $4 \mathrm{~min}$ in a laboratory Stomacher blender (Seward Ltd, London, UK). The yeast and mold numbers were determined by preparing serial dilutions and using the pour plate technique, with $40.0 \mathrm{~g} / \mathrm{L}$ of Yeast Extract Glucose Chloramphenicol Agar (YGC agar, DIFCO, West Molesey, Surrey, UK). The yeast and mold colony-forming units (cfu) were enumerated separately, according to their macromorphological features, on plates that yielded 1 to $100 \mathrm{cfu}$, after incubation at $25^{\circ} \mathrm{C}$ for 3 and $5 \mathrm{~d}$ for the yeasts and molds, respectively.

\subsection{Statistical Analysis}

The microbial counts were $\log _{10}$ transformed and were presented on a wet weight basis. The values below the detection limit for yeast and mold (detection levels: $10 \mathrm{cfu} / \mathrm{g}$ of silage) were assigned a value corresponding to half of the detection limit in order to calculate the average. The fermentative characteristics, microbial counts and aerobic stability were analyzed separately for the conservation periods and for the plastic covers. Data were analyzed for their statistical significance, via analysis of variance (ANOVA), with their significance reported at a 0.05 probability level, using the Statistical Package for Social Science (v 25.0, SPSS Inc., Chicago, IL, USA). When the calculated values of F were significant, the REGWF test $(\mathrm{P}<0.05)$ was used to interpret any significant differences among the mean values.

\section{Results}

\subsection{Forage Characteristics at Ensiling}

Table 1 lists the main characteristics of the whole corn forage prior to ensiling.

Table 1. Chemical and microbial characteristics of the chopped corn prior to ensiling.

\begin{tabular}{cc}
\hline Item & Value \\
\hline DM, \% & $40.9 \pm 2.1$ \\
pH & $5.89 \pm 0.07$ \\
Water activity, $\mathrm{a}_{\mathrm{w}}$ & $0.981 \pm 0.002$ \\
Buffering capacity, mEq/kg DM & $87.1 \pm 9.1$ \\
Nitrate content $(\mathrm{mg} / \mathrm{kg} \mathrm{DM})$ & $<100$ \\
$\mathrm{NH}_{3}-\mathrm{N}, \% \mathrm{TN}$ & $0.45 \pm 0.24$ \\
$\mathrm{NDF}_{\%} \% \mathrm{DM}$ & $37.9 \pm 1.3$ \\
ADF, \% DM & $21.4 \pm 1.2$ \\
Lignin, \% DM & $2.6 \pm 0.16$ \\
CP, \% DM & $6.8 \pm 0.85$ \\
Ether Extract, \% DM & $2.7 \pm 0.12$ \\
Ash, \% DM & $3.9 \pm 0.46$ \\
Starch, \% DM & $36.6 \pm 2.6$ \\
Lactic acid bacteria, log $10 \mathrm{cfu} / \mathrm{g}$ & $5.97 \pm 0.32$ \\
Yeasts, $\log _{10} \mathrm{cfu} / \mathrm{g}$ & $8.04 \pm 0.22$ \\
Molds, $\log _{10} \mathrm{cfu} / \mathrm{g}$ & $6.67 \pm 0.43$
\end{tabular}

Abbreviations: $\overline{\mathrm{ADF}}=$ acid detergent fiber; $\mathrm{cfu}=$ colony-forming units; $\mathrm{CP}=$ crude protein; $\mathrm{DM}=$ dry matter; $\mathrm{NDF}=$ neutral detergent fiber; $\mathrm{NH}_{3}-\mathrm{N}=$ ammonia nitrogen; $\mathrm{TN}=$ total nitrogen. 
The DM content, $\mathrm{CP}$, starch and fiber contents were typical of whole corn forage harvested at a more than $70 \%$ kernel milk line and represent the typical values for whole corn silage in the Po plain. No nitrates were present at ensiling. Soluble carbohydrates were around $60 \mathrm{~g} / \mathrm{kg}$ of the DM, and the buffering capacity was below $100 \mathrm{mEq} / \mathrm{kg}$ DM. The microbial counts of the yeasts and molds were higher than 8.0 and $6.0 \log \mathrm{cfu} / \mathrm{g}$, respectively, whereas the epiphytic LAB was around $6.0 \mathrm{log} \mathrm{cfu} / \mathrm{g}$.

\subsection{Temperature During the Experiment}

The ambient temperatures during the experimental period is reported in Table 2. The mean ambient temperature was around $19^{\circ} \mathrm{C}$ at ensiling. The ambient temperature decreased during the first months of conservation and reached a minimum value of $-7.2^{\circ} \mathrm{C}$, whereas it started to increase after $185 \mathrm{~d}$ of conservation

Table 2. Ambient temperature $\left({ }^{\circ} \mathrm{C}\right)$ during the experimental period.

\begin{tabular}{ccccc}
\hline & Data & Mean T & Max T & Min T \\
\hline Ensiling & 7 Sept & 18.9 & 27.4 & 13.1 \\
21 d & 28 Sept & 17.8 & 27.6 & 10.5 \\
85 d & 01 Dec & 4.5 & 12.0 & -0.4 \\
133 d & 18 Jan & -3.4 & 2.3 & -7.2 \\
185d & 10 Mar & 5.7 & 14.1 & -1.6 \\
230 d & 24 Apr & 13.7 & 21.2 & 7.8 \\
\hline
\end{tabular}

\subsection{Fermentative Profile}

The $\mathrm{pH}$ evolution in corn silage, as affected by the time of conservation, the distance from the plastic film and the type of plastic cover, is reported in Figure 1.

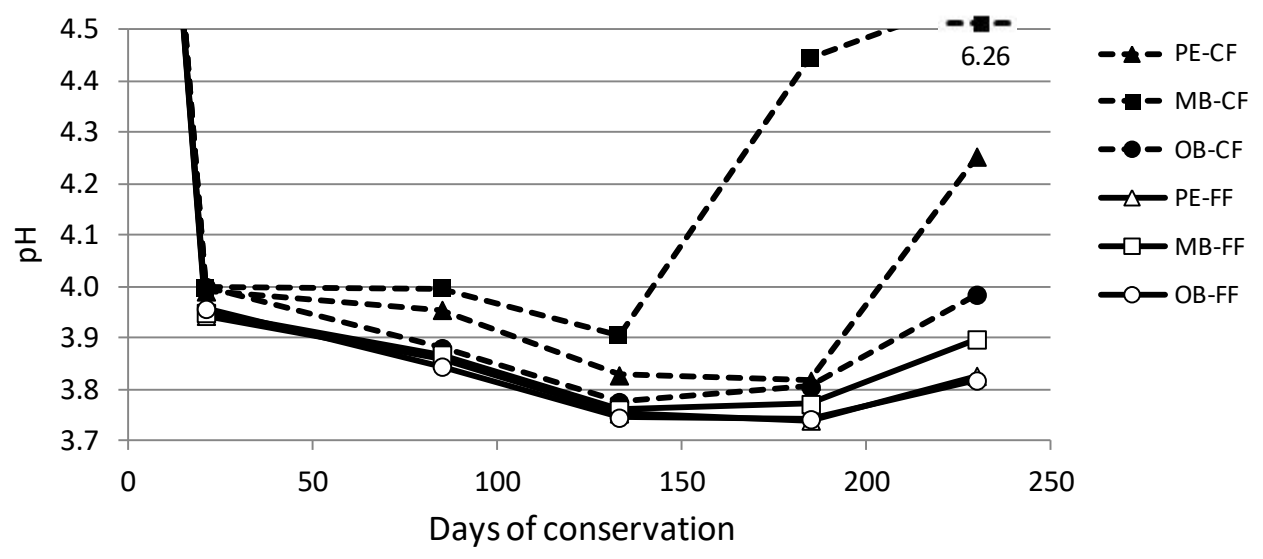

\begin{tabular}{cccccccc}
\hline & \multicolumn{7}{c}{ Days of Conservation } \\
\cline { 2 - 8 } Film & $\mathbf{2 1}$ & $\mathbf{8 5}$ & $\mathbf{1 3 3}$ & $\mathbf{1 8 5}$ & $\mathbf{2 3 0}$ & $\boldsymbol{P}$ & SE \\
\hline PE-CF & $\mathrm{aB}$ & $\mathrm{aB}$ & $\mathrm{bB}$ & $\mathrm{bB}$ & $\mathrm{bA}$ & 0.003 & 0.045 \\
MB-CF & $\mathrm{aB}$ & $\mathrm{aB}$ & $\mathrm{aB}$ & $\mathrm{aB}$ & $\mathrm{aA}$ & $<0.001$ & 0.226 \\
OB-CF & $\mathrm{aA}$ & $\mathrm{bB}$ & $\mathrm{cB}$ & $\mathrm{bB}$ & $\mathrm{cA}$ & $<0.001$ & 0.023 \\
PE-FF & $\mathrm{bA}$ & $\mathrm{bC}$ & $\mathrm{cD}$ & $\mathrm{bD}$ & $\mathrm{cB}$ & $<0.001$ & 0.017 \\
MB-FF & $\mathrm{bA}$ & $\mathrm{bA}$ & $\mathrm{cB}$ & $\mathrm{bB}$ & $\mathrm{cA}$ & $<0.001$ & 0.018 \\
OB-FF & $\mathrm{bA}$ & $\mathrm{bB}$ & $\mathrm{cD}$ & $\mathrm{bD}$ & $\mathrm{cC}$ & $<0.001$ & 0.018 \\
\hline & $<0.001$ & $<0.001$ & $<0.001$ & 0.001 & $<0.001$ & & \\
SE & 0.052 & 0.012 & 0.012 & 0.064 & 0.197 & & \\
\hline
\end{tabular}

Figure 1. The $\mathrm{pH}$ evolution in corn silage, as affected by the time of conservation and the type of plastic cover. Means with a different lowercase letter in the table, within the same column, are different; means with a different uppercase letter in the same row are different. The values at ensiling were not included in the statistical analysis. 
The $\mathrm{pH}$ decreased from ensiling to 133 days of conservation in all the silages. After 133 days, MB-CF showed a rapid increase in $\mathrm{pH}$, which reached 6.26 at 230 days of conservation. The $\mathrm{pH}$ in the silages covered with $\mathrm{PE}$ and $\mathrm{OB}$ plastic films started to increase after 185 days of conservation, that is, when the temperature started to increase in spring. The $\mathrm{pH}$ was higher in the $\mathrm{CF}$ areas than in the FF areas, regardless of the type of plastic cover. The MB film showed a $\mathrm{pH}$ increase in the peripheral areas after $133 \mathrm{~d}$. The OB cover determined the lowest values of $\mathrm{pH}$ in both the $\mathrm{CF}$ and FF areas. The lactic, acetic and propionic acid evolutions in corn silage, as affected by the time of conservation and the type of plastic cover, are reported in Figures 2-4, respectively. Lactic acid increased in the FF areas until 133 days of conservation, regardless of the type of plastic cover, and then remained constant. However, the CF areas showed lower lactic acid values than the FF areas. Lactic acid decreased significantly in the MB-CF and PE-CF films after 133 and 185 days of conservation, respectively. Acetic acid greatly increased in the FF areas after 85 days of conservation. A similar trend was observed in $\mathrm{PE}-\mathrm{CF}$ and $\mathrm{OB}-\mathrm{CF}$, albeit with higher values. The MB-CF showed the greatest increase in acetic acid until 133 days of conservation, after which it quickly decreased, consistently with the propionic acid content trend. No practical differences were observed in the propionic acid content at 21 and 85 days of ensiling between PE, OB and MB-FF. The ethanol evolution in the corn silage is reported in Figure 5. The ethanol content in the FF areas was typical of corn silage harvested at $40 \% \mathrm{DM}$, with values of around $16 \mathrm{~g} / \mathrm{kg}$ DM. OB-CF showed the highest value of ethanol (up to $20 \mathrm{~g} / \mathrm{kg} \mathrm{DM}$ ) until 133 days of conservation, and it decreased after a longer conservation period. The ethanol content in MB-CF decreased significantly after 85 days of ensiling, and it was under the detection limit at 230 days.

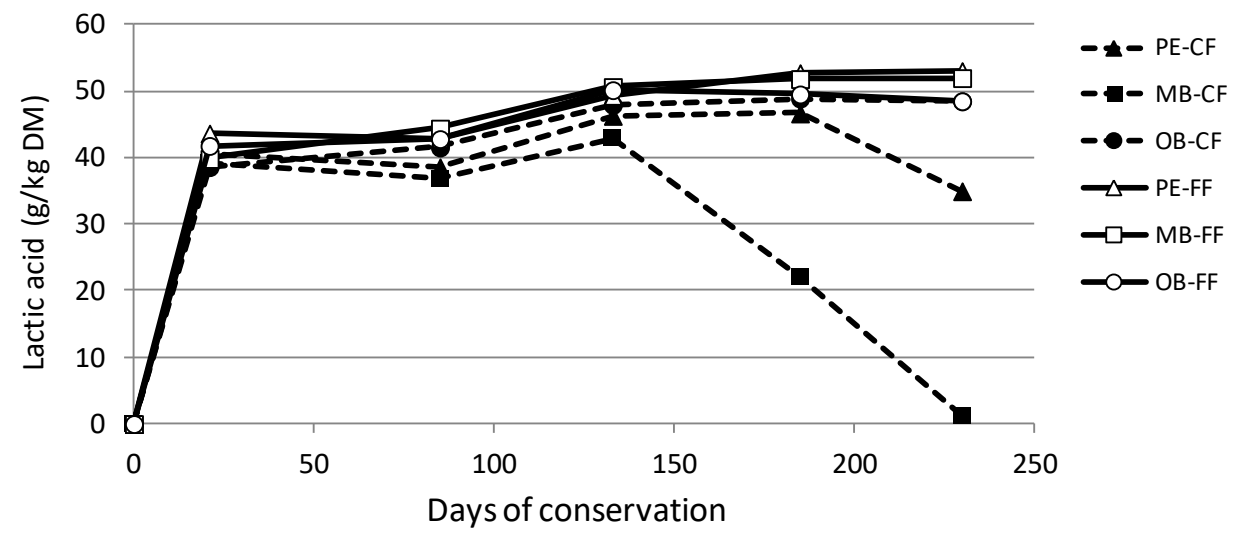

\begin{tabular}{cccccccc}
\hline & \multicolumn{7}{c}{ Days of Conservation } \\
\cline { 2 - 8 } Film & $\mathbf{2 1}$ & $\mathbf{8 5}$ & $\mathbf{1 3 3}$ & $\mathbf{1 8 5}$ & $\mathbf{2 3 0}$ & $\mathbf{P}$ & SE \\
\hline PE-CF & $\mathrm{abA}$ & $\mathrm{cA}$ & $\mathrm{bA}$ & $\mathrm{aA}$ & $\mathrm{bB}$ & 0.030 & 2.02 \\
MB-CF & $\mathrm{abA}$ & $\mathrm{bcA}$ & $\mathrm{cA}$ & $\mathrm{bB}$ & $\mathrm{cC}$ & $<0.001$ & 3.81 \\
OB-CF & $\mathrm{bB}$ & $\mathrm{abB}$ & $\mathrm{abA}$ & $\mathrm{aA}$ & $\mathrm{abA}$ & $<0.001$ & 1.01 \\
PE-FF & $\mathrm{aC}$ & $\mathrm{aB}$ & $\mathrm{abA}$ & $\mathrm{aA}$ & $\mathrm{aA}$ & $<0.001$ & 1.08 \\
MB-FF & $\mathrm{abB}$ & $\mathrm{aB}$ & $\mathrm{aA}$ & $\mathrm{aA}$ & $\mathrm{aA}$ & $<0.001$ & 1.15 \\
OB-FF & $\mathrm{abB}$ & $\mathrm{aB}$ & $\mathrm{abAB}$ & $\mathrm{aA}$ & $\mathrm{abA}$ & $<0.001$ & 0.89 \\
P & 0.038 & $<0.001$ & $<0.001$ & $<0.001$ & $<0.001$ & & \\
SE & 0.522 & 0.636 & 0.640 & 2.54 & 4.04 & & \\
\hline
\end{tabular}

Figure 2. Lactic acid evolution in corn silage, as affected by the time of conservation and the type of plastic cover. Means with a different lowercase letter in the table, within the same column, are different; means with a different uppercase letter in the same row are different. The values at ensiling were not included in the statistical analysis. 


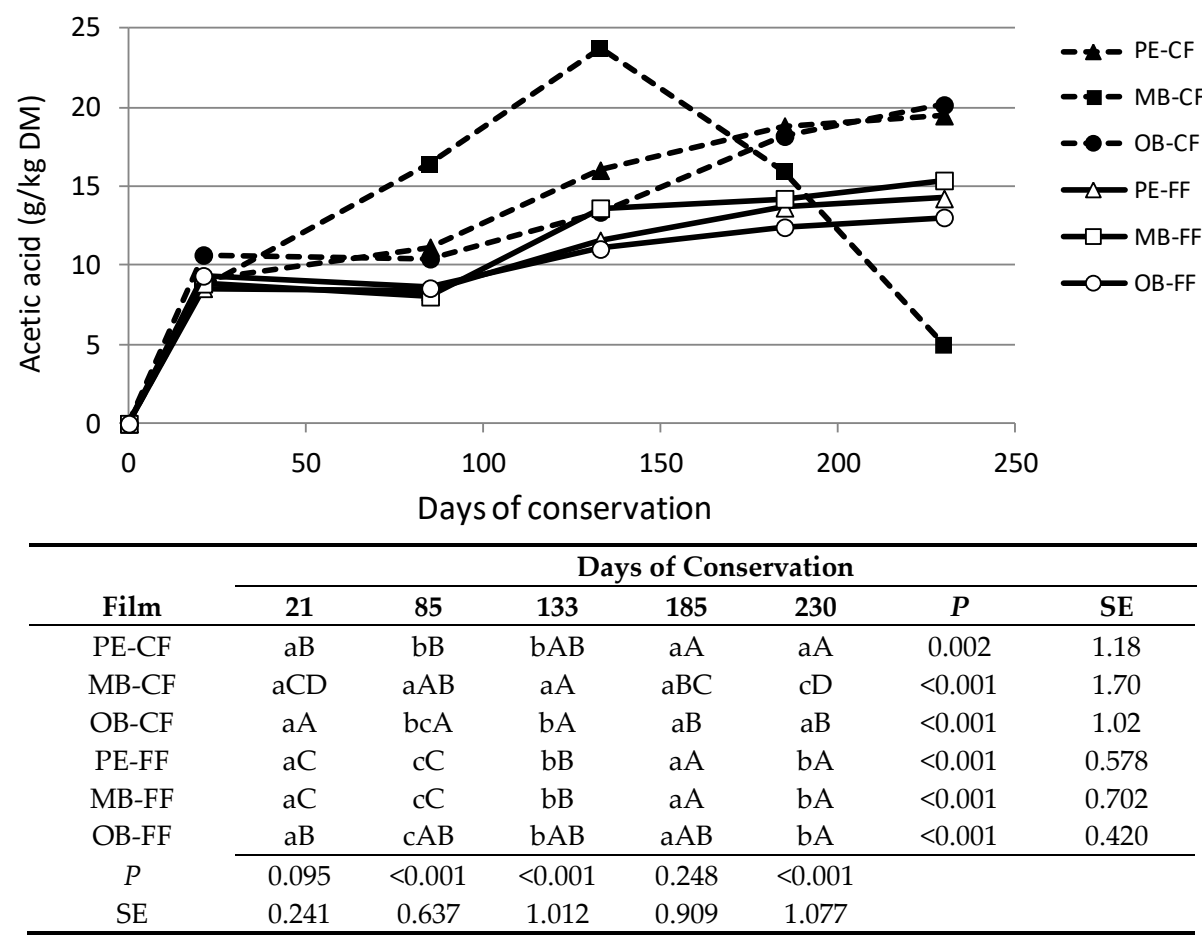

Figure 3. Acetic acid evolution in the corn silage, as affected by the time of conservation and the type of plastic cover. Means with a different lowercase letter in the table, within the same column, are different; means with a different uppercase letter in the same row are different. The values at ensiling were not included in the statistical analysis.

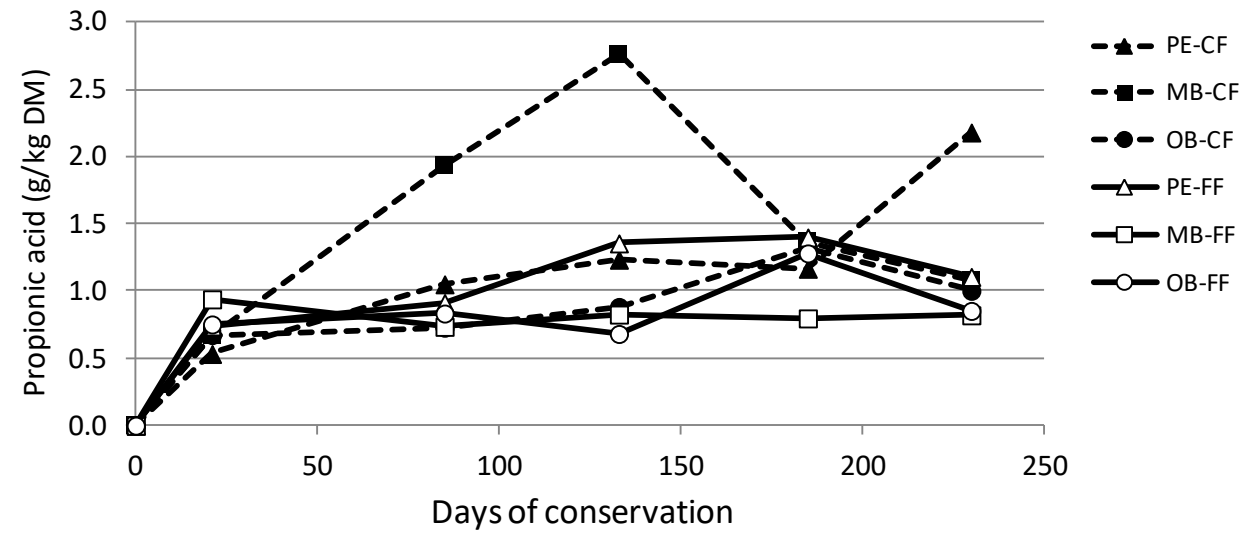

\begin{tabular}{cccccccc}
\hline & \multicolumn{7}{c}{ Days of Conservation } \\
\cline { 2 - 8 } Film & $\mathbf{2 1}$ & $\mathbf{8 5}$ & $\mathbf{1 3 3}$ & $\mathbf{1 8 5}$ & $\mathbf{2 3 0}$ & $\boldsymbol{P}$ & SE \\
\hline PE-CF & $\mathrm{dC}$ & $\mathrm{bBC}$ & $\mathrm{bB}$ & $\mathrm{aB}$ & $\mathrm{aA}$ & $<0.001$ & 0.136 \\
MB-CF & $\mathrm{cB}$ & $\mathrm{aAB}$ & $\mathrm{aA}$ & $\mathrm{aAB}$ & $\mathrm{bB}$ & 0.010 & 0.222 \\
OB-CF & $\mathrm{aA}$ & $\mathrm{bA}$ & $\mathrm{bA}$ & $\mathrm{bA}$ & $\mathrm{bA}$ & 0.277 & 0.029 \\
PE-FF & $\mathrm{cD}$ & $\mathrm{bD}$ & $\mathrm{bC}$ & $\mathrm{aA}$ & $\mathrm{bB}$ & $<0.001$ & 0.054 \\
MB-FF & $\mathrm{bcC}$ & $\mathrm{bAB}$ & $\mathrm{bB}$ & $\mathrm{aA}$ & $\mathrm{bA}$ & $<0.001$ & 0.063 \\
OB-FF & $\mathrm{bB}$ & $\mathrm{bB}$ & $\mathrm{bB}$ & $\mathrm{aA}$ & $\mathrm{bB}$ & 0.003 & 0.060 \\
\cline { 2 - 8 }$P$ & $<0.001$ & $<0.001$ & $<0.001$ & $<0.001$ & 0.017 & & \\
SE & 0.026 & 0.100 & 0.168 & 0.049 & 0.135 & & \\
\hline
\end{tabular}

Figure 4. Propionic acid evolution in the corn silage, as affected by the time of conservation and the type of plastic cover. Means with a different lowercase letter in the table, within the same column, are different; means with a different uppercase letter in the same row are different. The values at ensiling were not included in the statistical analysis. 


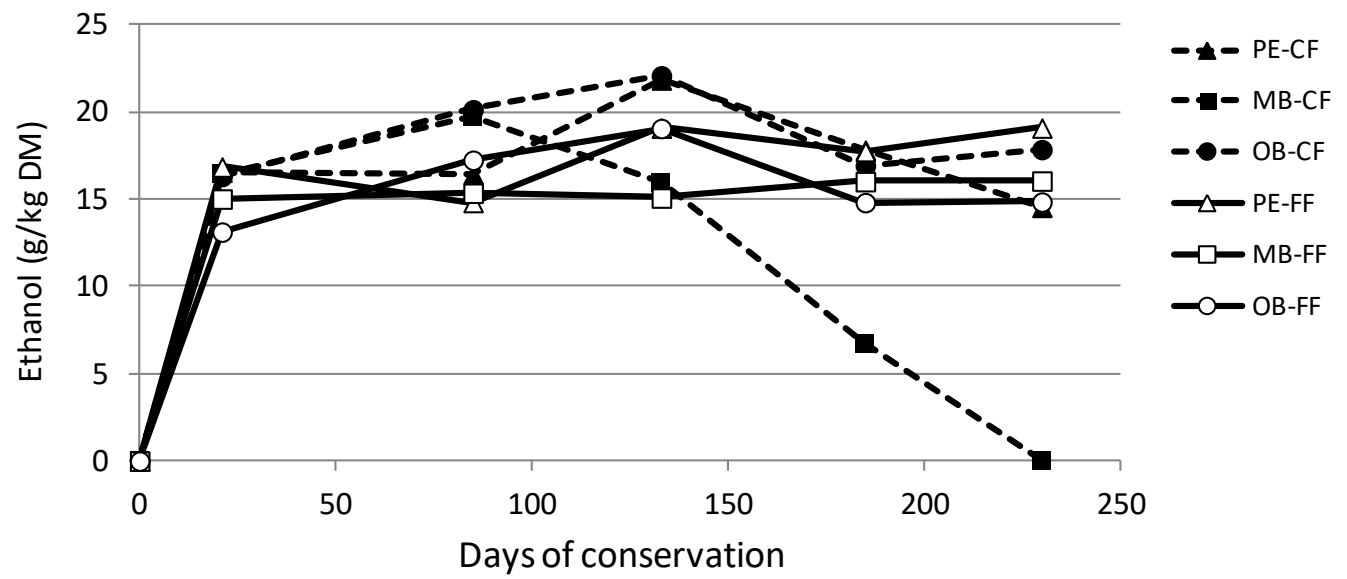

\begin{tabular}{cccccccc}
\hline & \multicolumn{7}{c}{ Days of Conservation } \\
\cline { 2 - 8 } Film & $\mathbf{2 1}$ & $\mathbf{8 5}$ & $\mathbf{1 3 3}$ & $\mathbf{1 8 5}$ & $\mathbf{2 3 0}$ & $\boldsymbol{P}$ & SE \\
\hline PE-CF & $\mathrm{aAB}$ & $\mathrm{bcAB}$ & $\mathrm{aA}$ & $\mathrm{aAB}$ & $\mathrm{aB}$ & 0.044 & 0.825 \\
MB-CF & $\mathrm{aA}$ & $\mathrm{aA}$ & $\mathrm{bA}$ & $\mathrm{bB}$ & $\mathrm{bC}$ & $<0.001$ & 1.80 \\
OB-CF & $\mathrm{aA}$ & $\mathrm{aA}$ & $\mathrm{aA}$ & $\mathrm{aA}$ & $\mathrm{aA}$ & 0.051 & 0.736 \\
PE-FF & $\mathrm{aB}$ & $\mathrm{dB}$ & $\mathrm{abA}$ & $\mathrm{aAB}$ & $\mathrm{aA}$ & $<0.001$ & 0.418 \\
MB-FF & $\mathrm{aA}$ & $\mathrm{cdA}$ & $\mathrm{bA}$ & $\mathrm{aA}$ & $\mathrm{aA}$ & 0.369 & 0.211 \\
OB-FF & $\mathrm{bB}$ & $\mathrm{bA}$ & $\mathrm{abA}$ & $\mathrm{aB}$ & $\mathrm{aB}$ & $<0.001$ & 0.523 \\
\hline & $<0.001$ & $<0.001$ & 0.002 & 0.004 & $<0.001$ & & \\
SE & 0.318 & 0.435 & 0.701 & 1.04 & 1.39 & & \\
\hline
\end{tabular}

Figure 5. Ethanol evolution in the corn silage, as affected by the time of conservation and the type of plastic cover. Means with a different lowercase letter in the table, within the same column, are different; means with a different uppercase letter in the same row are different. The values at ensiling were not included in the statistical analysis.

\subsection{Microbial Count and Aerobic Stability}

The yeast and mold evolution in the corn silage, as affected by the time of conservation and the type of plastic cover, is reported in Figures 6 and 7, respectively. During conservation, the yeast count decreased in the $\mathrm{PE}$ and $\mathrm{OB}$ plastic covers until 185 days of conservation. The OB plastic covers determined lower yeast counts than the $\mathrm{PE}$ ones for all the conservation periods. The yeast counts of the $\mathrm{MB}$ silages were close to those of $\mathrm{OB}$ at 21 and 85 days of conservation, after which they started to increase and exceeded $6.0 \mathrm{log} \mathrm{cfu} / \mathrm{g}$ in MB-CF after $133 \mathrm{~d}$ of conservation.

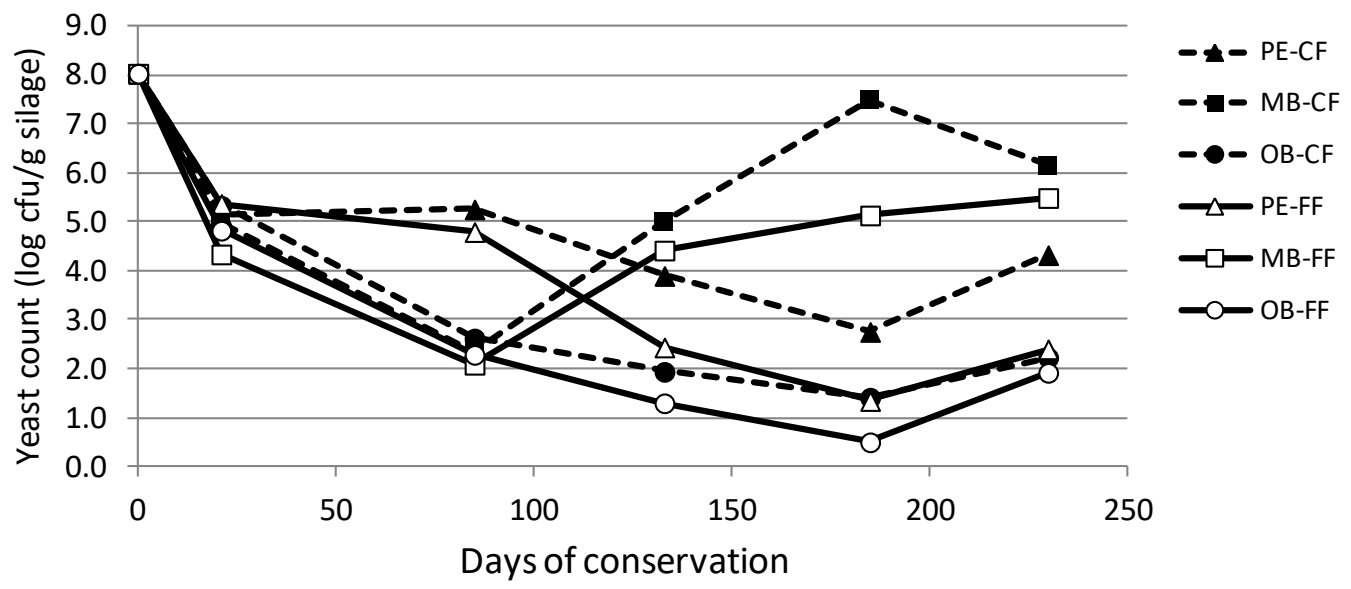

Figure 6. Cont. 


\begin{tabular}{cccccccc}
\hline & \multicolumn{7}{c}{ Days of Conservation } \\
\cline { 2 - 8 } Film & $\mathbf{2 1}$ & $\mathbf{8 5}$ & $\mathbf{1 3 3}$ & $\mathbf{1 8 5}$ & $\mathbf{2 3 0}$ & $\boldsymbol{P}$ & SE \\
\hline PE-CF & $\mathrm{aAB}$ & $\mathrm{aA}$ & $\mathrm{aBC}$ & $\mathrm{cC}$ & $\mathrm{bAB}$ & 0.001 & 0.249 \\
MB-CF & $\mathrm{abC}$ & $\mathrm{Bd}$ & $\mathrm{aC}$ & $\mathrm{aA}$ & $\mathrm{aB}$ & $<0.001$ & 0.400 \\
OB-CF & $\mathrm{aA}$ & $\mathrm{bB}$ & $\mathrm{bBC}$ & $\mathrm{dC}$ & $\mathrm{cBC}$ & $<0.001$ & 0.327 \\
PE-FF & $\mathrm{aA}$ & $\mathrm{aB}$ & $\mathrm{bC}$ & $\mathrm{dD}$ & $\mathrm{cC}$ & $<0.001$ & 0.378 \\
MB-FF & $\mathrm{cB}$ & $\mathrm{bB}$ & $\mathrm{aB}$ & $\mathrm{bB}$ & $\mathrm{abA}$ & $<0.001$ & 0.306 \\
OB-FF & $\mathrm{abA}$ & $\mathrm{bB}$ & $\mathrm{bBC}$ & $\mathrm{dC}$ & $\mathrm{cB}$ & $<0.001$ & 0.354 \\
$P$ & 0.007 & $<0.001$ & $<0.001$ & $<0.001$ & $<0.001$ & & \\
SE & 0.097 & 0.280 & 0.304 & 0.531 & 0.367 & & \\
\hline
\end{tabular}

Figure 6. Yeast count evolution in the corn silage, as affected by the time of conservation and the type of plastic cover. Means with a different lowercase letter in the table, within the same column, are different; means with a different uppercase letter in the same row are different. The values at ensiling were not included in the statistical analysis.

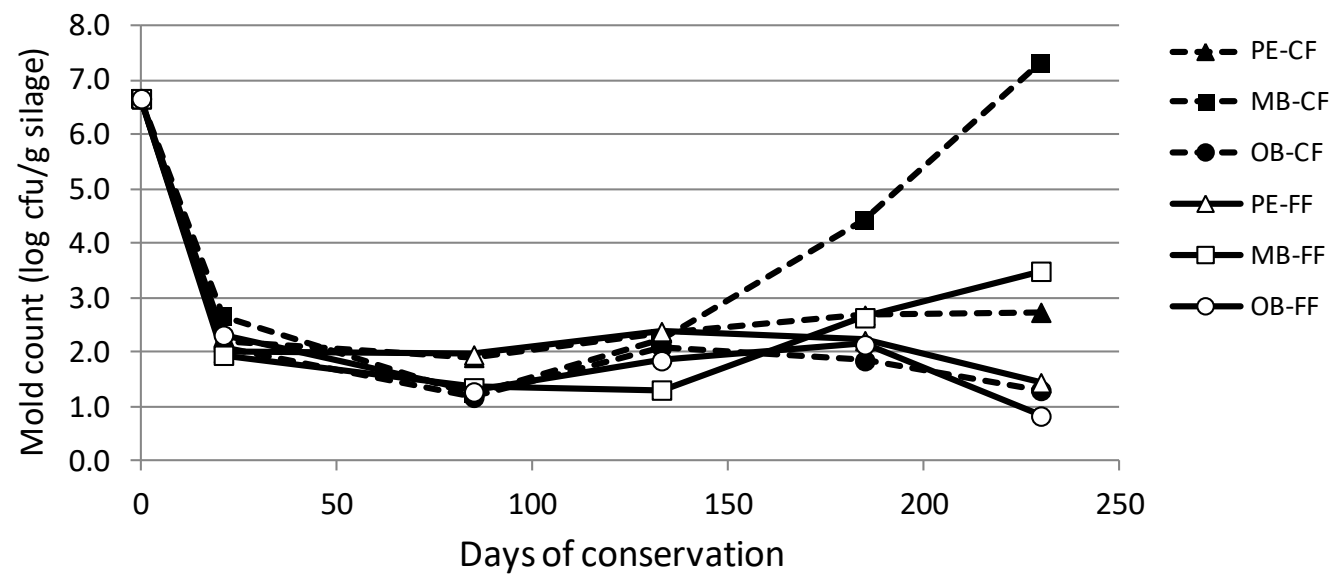

\begin{tabular}{cccccccc}
\hline & \multicolumn{7}{c}{ Days of Conservation } \\
\cline { 2 - 8 } Film & $\mathbf{2 1}$ & $\mathbf{8 5}$ & $\mathbf{1 3 3}$ & $\mathbf{1 8 5}$ & $\mathbf{2 3 0}$ & $\mathbf{P}$ & SE \\
\hline PE-CF & $\mathrm{aAB}$ & $\mathrm{abB}$ & $\mathrm{aAB}$ & $\mathrm{bAB}$ & $\mathrm{bA}$ & 0.027 & 0.101 \\
MB-CF & $\mathrm{aBC}$ & $\mathrm{bcC}$ & $\mathrm{aBC}$ & $\mathrm{aB}$ & $\mathrm{aA}$ & $<0.001$ & 0.559 \\
OB-CF & $\mathrm{aA}$ & $\mathrm{cA}$ & $\mathrm{aA}$ & $\mathrm{bA}$ & $\mathrm{cA}$ & 0.103 & 0.146 \\
PE-FF & $\mathrm{aA}$ & $\mathrm{aA}$ & $\mathrm{aA}$ & $\mathrm{bA}$ & $\mathrm{cA}$ & 0.222 & 0.133 \\
MB-FF & $\mathrm{aBC}$ & $\mathrm{abcC}$ & $\mathrm{aC}$ & $\mathrm{bAB}$ & $\mathrm{bA}$ & $<0.001$ & 0.216 \\
OB-FF & $\mathrm{aA}$ & $\mathrm{bcB}$ & $\mathrm{aC}$ & $\mathrm{bAC}$ & $\mathrm{cD}$ & $<0.001$ & 0.132 \\
\hline$P$ & 0.069 & $<0.001$ & 0.134 & 0.041 & $<0.001$ & & \\
SE & 0.076 & 0.091 & 0.131 & 0.278 & 0.475 & & \\
\hline
\end{tabular}

Figure 7. Mold count evolution in the corn silage, as affected by the time of conservation and the type of plastic cover. Means with a different lowercase letter in the table, within the same column, are different; means with a different uppercase letter in the same row are different. The values at ensiling were not included in the statistical analysis.

The longest conservation period (230 days) determined a 10-fold increase in the yeast counts in the $\mathrm{PE}$ and $\mathrm{OB}$ silages compared to the values at 185 days. Molds quickly decreased during ensiling and were around values of $2.0 \mathrm{log} \mathrm{cfu} / \mathrm{g}$ until 133 days. The mold count increased in the MB-CF and MB-FF silages after 133 days of ensiling and exceeded 7.0 log cfu/g in MB-CF. The aerobic stability evolution in the corn silage, as affected by the time of conservation and the type of plastic cover, is reported in Figure 8. The aerobic stability was higher in the FF areas than in the CF areas for each plastic cover, regardless of the conservation time. The OB covers determined higher aerobic stability than PE. The MB plastic covers showed the highest aerobic stability at 85 day of ensiling. The aerobic stability of MB quickly decreased after 85 days and became the lowest at 185 and 230 days. 


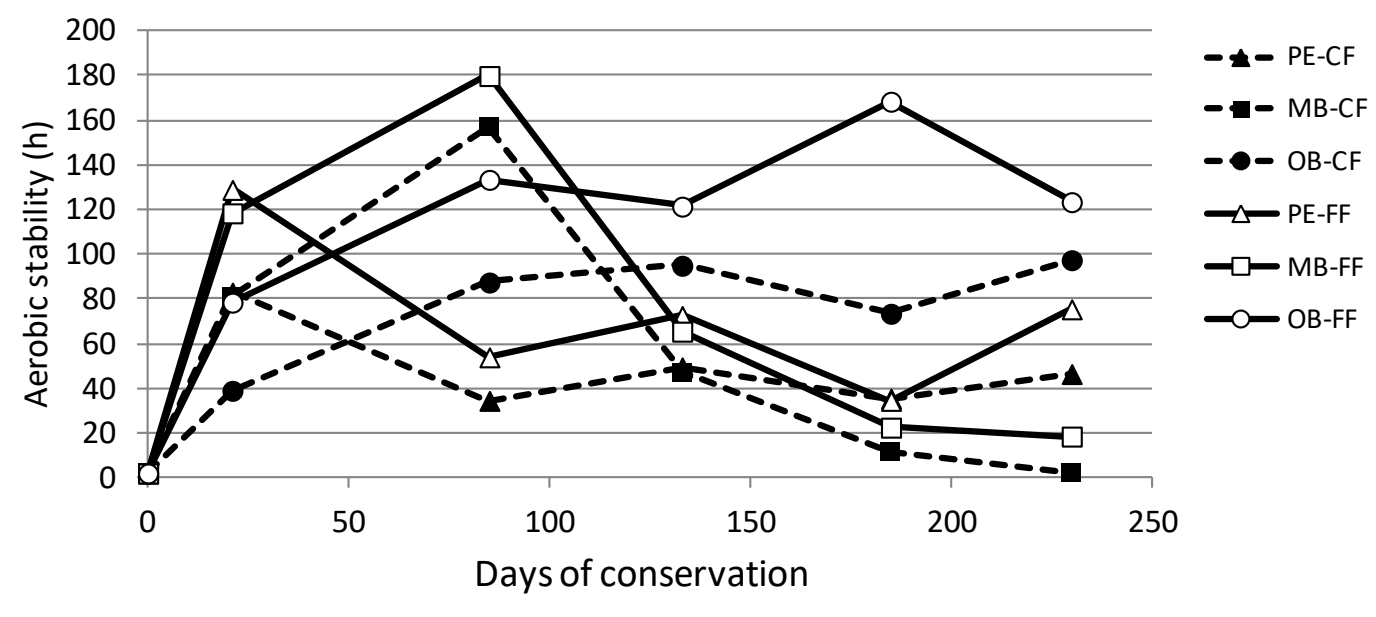

\begin{tabular}{cccccccc}
\hline & \multicolumn{7}{c}{ Days of Conservation } \\
\cline { 2 - 8 } Film & $\mathbf{2 1}$ & $\mathbf{8 5}$ & $\mathbf{1 3 3}$ & $\mathbf{1 8 5}$ & $\mathbf{2 3 0}$ & $\boldsymbol{P}$ & SE \\
\hline PE-CF & $\mathrm{bA}$ & $\mathrm{fB}$ & $\mathrm{cdB}$ & $\mathrm{cB}$ & $\mathrm{cdB}$ & 0.004 & 5.11 \\
MB-CF & $\mathrm{bB}$ & $\mathrm{bA}$ & $\mathrm{dC}$ & $\mathrm{dD}$ & $\mathrm{eD}$ & $<0.001$ & 13.0 \\
OB-CF & $\mathrm{cB}$ & $\mathrm{dA}$ & $\mathrm{bA}$ & $\mathrm{bA}$ & $\mathrm{abA}$ & $<0.001$ & 5.41 \\
PE-FF & $\mathrm{aA}$ & $\mathrm{eB}$ & $\mathrm{bcB}$ & $\mathrm{cB}$ & $\mathrm{bcB}$ & $<0.001$ & 7.88 \\
MB-FF & $\mathrm{aB}$ & $\mathrm{aA}$ & $\mathrm{cdC}$ & $\mathrm{cdD}$ & $\mathrm{deD}$ & $<0.001$ & 14.2 \\
OB-FF & $\mathrm{bC}$ & $\mathrm{cB}$ & $\mathrm{aB}$ & $\mathrm{aA}$ & $\mathrm{aB}$ & $<0.001$ & 7.51 \\
\cline { 2 - 8 }$P$ & $<0.001$ & $<0.001$ & $<0.001$ & $<0.001$ & $<0.001$ & & \\
SE & 6.97 & 11.2 & 5.88 & 11.2 & 9.39 & & \\
\hline
\end{tabular}

Figure 8. Aerobic stability of the corn silage, as affected by the time of conservation and the type of plastic cover. Means with a different lowercase letter in the table, within the same column, are different; means with a different uppercase letter in the same row are different. The values at ensiling were not included in the statistical analysis.

\section{Discussion}

The importance of ensuring stable anaerobic conditions to obtain uniform, high-quality silage over the whole profile is unquestionable $[3,33,34]$. The quality of the plastic film used to cover silages plays a key role in the obtained degree of anaerobiosis, especially in the 500 to $600 \mathrm{~mm}$ peripheral part close to the covering system $[4,9,35]$. The ideal film should have high mechanical and physical properties, high impermeability to oxygen, and costs related to the necessary quality requirements [8].

By the mid-1970s, the use of PE had become the conventional method of covering horizontal silos, and this practice remained unchanged for 30 years. The development of films with similar mechanical characteristics to those of a PE film, but with reduced permeability to oxygen (OB) (obtained by coextruding a layer of barrier polymer), has been shown to improve the quality of corn silage by reducing the yeast count and increasing in aerobic stability [36-38]. Borreani and Tabacco [9] found, in a commercial bunker silo, that the quality of the silage was improved, over the entire silo face, by use of an OB film, and spoiled silage was minimized $(<0.6 \%$ of the silo surface compared with $5.8 \%$ for the part covered with a PE film), especially in the corner areas close to the bunker walls where the DM density was lower and it is more difficult to seal the silos. In the present experiment, the use of an OB film has been confirmed to be a good solution to obtain well-fermented corn silages with a good silage fermentative profile ( $\mathrm{pH}$ and lactic acid). Moreover, the yeast and mold counts of the silage close to the film were very similar to those at a distance from the film throughout the entire conservation period, that is, until 230 days, whereas the aerobic stability was lower in CF than in FF. These results indicate that apart from a permeability to oxygen, the sealing procedures and the lower density of silage in peripheral areas also play roles in silage aerobic stability [5]. On the other hand, the PE film showed similar values in the FF and CF areas in the first period of conservation, until $133 \mathrm{~d}$, and then started to show significantly higher $\mathrm{pH}$ and yeast counts in the $\mathrm{CF}$ areas than in the FF ones. Comparing the film 
performances of OB with PE, better fermentation profiles and better aerobic stability appear from $21 \mathrm{~d}$ of conservation onwards. Borreani et al. [37] also reported a further increase in aerobic stability in silages covered with OB for longer conservation periods than 100 days. Accordingly, in the present work, the aerobic stability increased after 85 days of conservation.

In the last few years, there has been a strong pressure to replace petroleum-based plastic films with biodegradable material films [22,39]. Biodegradable films have been evaluated for this purpose, but their main drawback was found to be their proneness to begin biodegradation during silage conservation [22]. In the present experiment, five different conservation periods (from 21 to 230 days) have been evaluated to verify the effect of MB on silage quality. The MB films showed a positive role in the preservation of silage quality until 85 days of conservation, with similar yeast and mold counts to those of oxygen barrier films, and even better aerobic stability. The use of an MB plastic film in this period allows good silage fermentation, and comparable $\mathrm{pH}$, lactic acid and acetic acid with those obtained when using the commonly used PE and OB films to be achieved. This fermentative profile led to a yeast reduction and improved aerobic stability. After 85 days of conservation, the MB film began to biodegrade, and this led to a depletion of the fermentative products, an increase in the yeast and mold counts and a decrease in aerobic stability. These results indicate that the use of MB is not useful to avoid the aerobic deterioration of corn silage after about 3 months. Borreani et al. [21] and Borreani and Tabacco [22] reported, in plastic bag experiments, that a biodegradable film could be a promising alternative to a PE film for indoor conservation periods as long as 4 months. However, the considered biodegradable plastic films were less effective when utilized to cover silage under outdoor conditions [23], which are comparable with the conditions of the present experiment.

Plastic films play a fundamental role in the upper part of horizontal silos, which are difficult to seal properly [40] and are prone to spoilage [8]. The mechanical and physical properties (i.e., film integrity and oxygen impermeability) of a plastic film and their maintenance over the conservation period are key factors in the preservation of forage quality in the upper part of horizontal silos [4]. A characteristic that separated the MB films from the PE and OB films is their water vapor transmission rate (WVTR), which was 10-fold greater in the MB films than in the PE and OB ones. A greater WVTR has been reported to cause wilting in the upper part of silages covered with MB films [22]. The drawback of this characteristic is that as moisture is lost, the porosity of silage increases, and this could allow a more rapid movement of oxygen, thereby increasing the aerobic deterioration of silages. However, the three films that were tested in this experiment had very different oxygen permeability degrees, with OB showing the lowest value, that is, 1000-fold lower than in PE, and halfway between the two MB film. Before the biodegradation of MB, its low oxygen permeability determined a reduction in the yeast count in the upper part of silages, resulting in yeast count that was close to that of the central part (MB-FF). Interestingly, these values were close to those found in OB films, thus indicating a similar effect of the two plastic films in the first three month of conservation. The reduction in the yeast count led to higher aerobic stabilities of OB and MB than PE at 85 days of conservation. Several experiments $[9,11,36]$ reported that corn silage in the upper layer under an OB film had a lower yeast count and greater aerobic stability than silage stored under a conventional PE film. The increased aerobic stability and lower yeast count in the upper layer of the silage, stored under an OB film, have been attributed to reduced oxygen permeation through the silo seal during conservation. Further research is needed to find a biodegradable plastic film to cover silage that will be stable for periods of up to 8 months under outdoor conditions $[9,16]$ to combine the needs of farmers to have stable silages for long conservation periods and to reduce plastic consumption and waste production.

The length of conservation represents a critical point for the quality and stability of silage. A long conservation period in complete anaerobiosis determines a decrease in the yeast and mold counts and improves the aerobic stability of silages [41]. Aerobic stability has been found to be positively correlated with the length of conservation in laboratory-scale experiments [42]. However, it could be difficult to ensure complete anaerobiosis during a long conservation period under farm conditions. Plastic films can be punctured by a wide variety of sources (e.g. birds or rats) and this allows oxygen 
to penetrate. External heat sources (e.g., solar radiation) can increase the temperature of stored silage, thereby creating areas with conditions predisposed to silage deterioration [43]. Furthermore, the oxygen permeability of a plastic film is higher for high temperatures. In the present experiment, the yeast count increased slightly after 185 to 230 days of conservation. This could be attributed to an increase in the mean temperatures $\left(+8^{\circ} \mathrm{C}\right)$ of the environment. Interestingly, this trend was more evident in the peripheral areas of the PE films, whereas the OB-CF showed a yeast count close to those of OB-FF and PE-FF. The increase in yeast count of OB-FF determined a decrease in the aerobic stability.

\section{Conclusions}

The different types of plastic film used to cover silages is a key factor in obtaining a high quality silage, because they can determine different degrees of anaerobiosis in a bunker silo. Furthermore, they can have different degrees of stability over the conservation period. The results of this experiment have confirmed that the use of an oxygen barrier film allows high quality corn silages to be obtained with similar microbial and fermentative parameters for the areas close to and at a distance from the film. The positive effect of the oxygen barrier film has been found to last throughout the whole conservation period (more than 200 days). The conventional polyethylene film showed a good conservation effect until 133 days of conservation. Mater-Bi ${ }^{\circledR}$ the first completely biodegradable and compostable bio-based polymer, has shown similar characteristics to an OB film for three months of conservation, after which it began to biodegrade, thereby showing it was not useful for long-term silage preservation.

Author Contributions: E.T. and G.B. conceived and designed the experiments; all authors performed the experiments; E.T. and F.F. analyzed the data; E.T. and F.F. wrote the paper-original draft; E.T. and G.B. wrote the paper-review and editing; G.B. supervised, administered the project, acquired funding. All authors have read and agreed to the published version of the manuscript.

Acknowledgments: Mention of trade names or commercial products in this article is solely for the purpose of providing specific information and does not imply either recommendation or endorsement by the University of Turin (Turin, Italy). The authors thank Sara Guerrini and Roberto Ponti (Novamont SpA, Novara, Italy) for the development of the biodegradable plastic films used in the experiment. They also thank Mauro Gilli and Mario Gilardi [Department of Agricultural, Forest and Food Sciences (DISAFA), University of Turin, Italy] for technical assistance in the field and Serenella Piano (DISAFA) for the chemical and microbiological analyses.

Conflicts of Interest: The authors declare no conflict of interest.

\section{References}

1. Ferraretto, L.; Shaver, R.; Luck, B. Silage review: Recent advances and future technologies for whole-plant and fractionated corn silage harvesting. J. Dairy Sci. 2018, 101, 3937-3951. [CrossRef] [PubMed]

2. Pahlow, G.; Muck, R.E.; Driehuis, F.; Oude Elferink, S.J.W.H.; Spoelstra, S.F. Microbiology of ensiling. In Silage Science and Technology (Agronomy Series No. 42); Buxton, D.R., Muck, R.E., Harrison, H.J., Eds.; American Society of Agronomy: Madison, WI, USA, 2003; pp. 31-93.

3. Woolford, M.K. The detrimental effect of air on silage. J. Appl. Bacteriol. 1990, 68, 101-116. [CrossRef] [PubMed]

4. Borreani, G.; Tabacco, E.; Cavallarin, L. A new oxygen barrier film reduces aerobic deterioration in farm-scale corn silage. J. Dairy Sci. 2007, 90, 4701-4706. [CrossRef] [PubMed]

5. Borreani, G.; Tabacco, E.; Schmidt, R.J.; Holmes, B.J.; Muck, R.E. Silage review: Factors affecting dry matter and quality losses in silages. J. Dairy Sci. 2018, 101, 3952-3979. [CrossRef]

6. Anonymous. Packaged silage: Will plastics replaced silos? N. J. Agric. 1953, 35, 4-5.

7. Wilkinson, J.M.; Bolsen, K.K.; Lin, C.J. History of silage. In Silage Science and Technology (Agronomy Series No. 42); Buxton, D.R., Muck, R.E., Harrison, H.J., Eds.; American Society of Agronomy: Madison, WI, USA, 2003; pp. 1-30.

8. Borreani, G.; Tabacco, E. Plastics in Animal Production. In A Guide to the Manufacture, Performance, and Potential of Plastics in Agriculture; Orzolek, M.D., Ed.; Elsevier Science Oxford: Oxford, UK, 2017; pp. $145-185$.

9. Borreani, G.; Tabacco, E. Improving corn silage quality in the top layer of farm bunker silos through the use of a next-generation barrier film with high impermeability to oxygen. J. Dairy Sci. 2014, 97, 2415-2426. [CrossRef] 
10. Cavallarin, L.; Tabacco, E.; Antoniazzi, S.; Borreani, G. Aflatoxin accumulation in whole crop maize silage as a result of aerobic exposure. J. Sci. Food Agric. 2011, 91, 2419-2425. [CrossRef]

11. Dolci, P.; Tabacco, E.; Cocolin, L.; Borreani, G. Microbial dynamics during aerobic exposure of corn silage stored under oxygen barrier or polyethylene films. Appl. Environ. Microbiol. 2011, 77, 7499-7507. [CrossRef]

12. Wilkinson, J.M.; Fenlon, J.S. A meta-analysis comparing standard polyethylene and oxygen barrier film in terms of losses during storage and aerobic stability of silage. Grass Forage Sci. 2014, 69, 385-392. [CrossRef]

13. Kyrikou, I.; Briassoulis, D. Biodegradation of agricultural plastic films: A critical review. J. Polym. Environ. 2007, 15, 125-150. [CrossRef]

14. Bhatti, J.A. Current State and Potential for Increasing Plastics Recycling in the U.S. Master's Thesis, Columbia University, Sponsored by Earth Engineering Center, New York City, NY, USA, 2010.

15. Holmes, B.J.; Springman, R. Recycling Silo-Bags and Other Agricultural Plastic Films (A 3875); Cooperative Extension of the University of Wisconsin: Madison, WI, USA, 2009.

16. Borreani, G.; Dolci, P.; Tabacco, E.; Cocolin, L. Aerobic deterioration stimulates outgrowth of spore-forming Paenibacillus in corn silage stored under oxygen-barrier or polyethylene films. J. Dairy Sci. 2013, 96, 5206-5216. [CrossRef] [PubMed]

17. Savoie, P.; Bernier-Roy, M.; Pedneault, M.L.; Amyot, A. Evaluation of apple pulp and peanut butter as alternative bunker silo covers. Can. Biosyst. Eng. 2003, 45, 217-222.

18. Denoncourt, P.; Caillet, S.; Lacroix, M. Bacteriological and chemical changes occurring in bunker-stored silage covered with biodegradable coating. J. Appl. Microbiol. 2007, 103, 261-270. [CrossRef] [PubMed]

19. Razza, F.; Degli Innocenti, F. Bioplastics from renewable resources: The benefits of Biodegradability. Asia-Pac. J. Chem. Eng. 2012, 7, S301-S309. [CrossRef]

20. Bastioli, C. Properties and application of Mater-Bi starch-based materials. Polym. Degrad. Stab. 1998, 59, 263-272. [CrossRef]

21. Borreani, G.; Revello Chion, A.; Piano, S.; Ranghino, F.; Tabacco, E. A preliminary study on new biodegradable films to cover silages. In Proceedings of the 23rd General Meeting of the European Grassland Federation, Kiel, Germany, 29 August-2 September 2010; pp. 202-204.

22. Borreani, G.; Tabacco, E. Bio-based biodegradable film to replace the standard polyethylene cover for silage conservation. J. Dairy Sci. 2015, 98, 386-394. [CrossRef]

23. Spadaro, D.; Bustos-Lopez, M.P.; Gullino, M.L.; Piano, S.; Tabacco, E.; Borreani, G. Evolution of fungal populations in corn silage conserved under polyethylene or biodegradable films. J. Appl. Microbiol. 2015, 119, 510-520. [CrossRef]

24. American Society for Testing and Materials. ASTM standard method D3985-81; Annual Book of Standards; ASTM: Philadelphia, PA, USA, 1980.

25. American Society for Testing and Materials. ASTM Standard Method F1249-06; Annual Book of Standards; ASTM: Philadelphia, PA, USA, 2011.

26. Porter, M.G.; Murray, R.S. The volatility of components of grass silage on oven drying and the inter-relationship between dry-matter content estimated by different analytical methods. Grass Forage Sci. 2001, 56, 405-411. [CrossRef]

27. DuBois, M.; Gilles, K.A.; Hamilton, J.K.; Rebers, P.A.; Smith, F. Colorimetric method for determination of sugars and related substances. Anal. Chem. 1956, 28, 350-356. [CrossRef]

28. AOAC International. Official Methods of Analysis, 18th ed.; AOAC International: Gaithersburg, MD, USA, 2005.

29. Van Soest, P.J.; Robertson, J.B.; Lewis, B.A. Methods of dietary fiber, neutral detergent fiber, and nonstarch polysaccharides in relation to animal nutrition. J. Dairy Sci. 1991, 74, 3583-3597. [CrossRef]

30. Robertson, J.B.; Van Soest, P.J. The detergent system of analysis and its application to human foods. In The Analysis of Dietary Fiber in Food; James, W.P.T., Theander, O., Eds.; Marcel Dekker: New York, NY, USA, 1981; pp. 123-158.

31. Playne, M.J.; McDonald, P. The buffering constituents of herbage and of silage. J. Sci. Food Agric. 1966, 17, 264-268. [CrossRef]

32. Canale, A.; Valente, M.E.; Ciotti, A. Determination of volatile carboxylic acids (C1-C5) and lactic acid in aqueous acid extracts of silage by high performance liquid chromatography. J. Sci. Food Agric. 1984, 35, 1178-1182. [CrossRef]

33. Muck, R.E. Recent advances in silage microbiology. Agric. Food Sci. 2013, 22, 3-15. [CrossRef] 
34. Wilkinson, J.M.; Davies, D.R. The aerobic stability of silage: Key findings and recent developments. Grass Forage Sci. 2013, 68, 1-19. [CrossRef]

35. Bolsen, K.K.; Dickerson, J.T.; Brent, B.E.; Sonon, R.N., Jr.; Dalke, B.S.; Lin, C.; Boyer, J.E., Jr. Rate and extent of top spoilage losses in horizontal silos. J. Dairy Sci. 1993, 76, 2940-2962. [CrossRef]

36. Orosz, S.; Wilkinson, J.M.; Wigley, S.; Bìrò, Z.; Gallo, J. Microbial status, aerobic stability and fermentation of maize silage sealed with an oxygen barrier film. Agric. Food Sci. 2013, 22, 182-188. [CrossRef]

37. Borreani, G.; Piano, S.; Tabacco, E. Aerobic stability of maize silage stored under plastic films with different oxygen permeability. J. Sci. Food Agric. 2014, 94, 2684-2690. [CrossRef] [PubMed]

38. Lima, L.M.; Dos Santos, J.P.; Casagrande, D.R.; Ávila, C.L.S.; Lara, M.S.; Bernardes, T.F. Lining bunker walls with oxygen barrier film reduces nutrient losses in corn silages. J. Dairy Sci. 2017, 100, 4565-4573. [CrossRef]

39. Guerrini, S.; Borreani, G.; Voojis, H. Biodegradable materials in agriculture: Case histories and perspectives. In Soil Degradable Bioplastics for a Sustainable Modern Agriculture; Malinconico, M., Ed.; Springer International Publishing AG: Berlin, Germany, 2017; pp. 35-65.

40. Ashbell, G.; Lisker, N. Aerobic deterioration in maize silage stored in a bunker silos under farm conditions in a subtropical climate. J. Sci. Food Agric. 1988, 45, 307-315. [CrossRef]

41. McDonald, P.; Henderson, A.R.; Heron, S.J.E. The Biochemistry of Silage, 2nd ed.; Chalcombe Publications: Bucks, PA, USA, 1991.

42. Ferrero, F.; Piano, S.; Tabacco, E.; Borreani, G. Effects of conservation period and Lactobacillus hilgardii inoculum on the fermentation profile and aerobic stability of whole corn and sorghum silages. J. Food Sci. Agric. 2019, 99, 2530-2540. [CrossRef]

43. Green, O.; Bartzanas, T.; Løkke, M.M.; Bochtis, D.D.; Sørensen, C.G.; Jørgensen, O.J.; Tortajada, V.G. Spatial and temporal variation of temperature and oxygen concentration inside silage stacks. Biosyst. Eng. 2012, 111, 155-165. [CrossRef]

(C) 2020 by the authors. Licensee MDPI, Basel, Switzerland. This article is an open access article distributed under the terms and conditions of the Creative Commons Attribution (CC BY) license (http://creativecommons.org/licenses/by/4.0/). 